\title{
Collaborative Governance in MSMEs Development (Case Study: Collaboration Model of Surabaya Local Government, Private, and MSMEs Association in MSMEs Development at Coastal Area of Surabaya)
}

\author{
Mas Roro Lilik Ekowanti ${ }^{1}$, Arie Ambarwati ${ }^{2}$ \\ Lilik.ekowanti@hangtuah.ac.id ${ }^{1}$, Arie.ambarwati@hangtuah.ac.id ${ }^{2}$
}

Hang Tuah University Surabaya

\begin{abstract}
One of the strategies to increase economic growth, Indonesia develops Micro Small and Medium Enterprises (MSMEs). In the last 5 years, the number of macro-level enterprises has increased, in other hand the number of micro-level enterprise has declined. Surabaya City which is the second largest city in Indonesia has a good potential in increasing economic growth, especially in the sector of MSMEs. Data show that at the level of micro, small and medium enterprise tend to increase in Surabaya. The research question is how the collaborative model of Surabaya Government, Private and MSMEs Association in the MSMEs development at coastal area of Surabaya? This study used theory collaboration model from Agranoff-Mc Guire based on two dimensions of activity and strategy, which resulted in six combinations of collaboration model that are Jurisdiction Based Model, Abstinence Model, Top Down Model, Donor Recipient Model, Reactive Model and Contended Model. The research method used qualitative approach with action research type. Data analysis technique referred to Miles Huberman that were data collection, data reduction, data display, and conclusion. The preliminary conclusion in this research is that collaborative model of Surabaya Government, Private, and Association of UMKM is Jurisdiction-Based Model. All parties have a high interest in the development of MSMEs in the Coastal area of Surabaya.
\end{abstract}

Keywords: Collaboration, Collaboration Model, Development of MSMEs in the Coastal Area of Surabaya

\section{Introduction}

Collaboration between local governments to create a regional approach to economic development is one way to achieve synergy and generate momentum that drives a lasting economy[1]. Efforts to build the economy in regional government are partnerships, institutional coordination, and fragmentation. Three models were explored in the context of entrepreneurial economics in three regions [2]. The four regions in which collaboration takes place can contribute to collaboration, public-private collaboration, collaboration between industry operators, and collaboration with other industries[3].

While collaboration can be an effective approach to service delivery for local governments, local governments are looking for the lack of costs in improving innovation services or better relations with the community[4]. Collaboration as a drug in the lack of innovation in the public 
sector is a public responsibility[5]. The development of an official e-collaborative platform provides promising new opportunities to promote mutually beneficial collaboration between government and citizens, and to encourage public sector innovation[6]. Cross-sector collaboration is increasingly relied on to overcome community pressures and problems that are difficult to solve by the government[7]. Public-private partnership (PPP) is understood as a collaborative tool that can be used to achieve efficiency and innovation[8].

The collaboration strategy between the government and the private sector has been carried out by the Regional Government of Surabaya City in the development of MSMEs. The city of Surabaya which is the second largest city in Indonesia and the capital city of East Java Province has good potential in increasing economic growth, especially in the MSMEs sector. In table 1 it can be seen that the number of SIUP at the level of micro, small and medium industrial enterprises tends to increase.

Table 1. Number of SIUP of Trade / and Industry in Surabaya City

\begin{tabular}{|c|c|c|c|c|}
\hline No. & Year & Micro & Small & Medium \\
\hline 1 & 2014 & 1.373 & 3.437 & 1.359 \\
\hline 2 & 2015 & 1.538 & 4.062 & 1.531 \\
\hline 3 & 2016 & 2.498 & 6.462 & 2.212 \\
\hline
\end{tabular}

Source: processed from Surabaya in numbers, 2014-2016

In the last 3 years, a significant increase occurred in 2015 towards 2016, namely $56.7 \%$. The success of increasing MSMEs in Surabaya is certainly inseparable from the role of the Surabaya City Government in designing MSMEs development strategies with related stakeholders. Therefore, this research was appointed under the title of Collaboration and Partnership Model of Surabaya City Government, Private and MSMEs Associations in the Development of MSMEs in the Coastal Area of Surabaya City. Then the formulation of the problem of this research is how is the collaboration model and partnership of the Surabaya City Government with the MSMEs Association in the development of MSMEs in the coastal area of Surabaya city.

\section{Methods}

This type of research is action research. action research, trying to describe the facts and reality as they are. This research also used a qualitative approach that contains the meaning of a description of the data using words and sentence lines. Then the data collection techniques used were purposive and snow ball, taken from individuals who have adequate information, in accordance with the research objectives, by using in-depth interview guidelines and observation. Then the data analysis technique referred to Miles and Huberman [9] which consisted of data collection, data reduction, data display, and conclusion.

\section{Results}

Research findings was done using a collaborative approach according to Agranoff and McGuire show that: Top Down and Jurisdiction-Based Management Models were more appropriate to observe the collaboration pattern of the government (Central and Regional), 
Private and Community (community groups) or the MSMEs of Surabaya City. In the findings analysis the pattern shows important factors in the implementation of the collaboration model of Top Down and Jurisdiction-Based Management Collaboration Model as follows:

\section{(1) Centralization of Authority (Top Down Collaboration Model)}

Top Down Collaboration Model has the element of (a) legal formalism, (b) centralized authority. These two elements are described as follows:

\section{a. Legal Formalism (Top Down Collaboration Model)}

As mandated in Law 23 of 2014 concerning Regional Autonomy that some mandatory obligations that should be carried out at the regional level, such as: MSEMs Policy as previously described, there seems to be overlapping authority. The problem of activities that are economic in nature, such as the management of MSMEs is a policy or program that is still a central authority in a implementative manner, thus it is centralized. Thus it is seen that the collaboration model that occurs tends to be top down. The characteristics of the implementation of legal formalism or top down are Grindle and Thomas[10] :

1) How far is the implementor and target group consistent with the decisions made?

2) To what extent is the goal achieved not deviating from its final goal?

3) What factors have the potential to influence efforts to achieve the goals and objectives that have been set.

4) How will the policy be updated based on the implementation experience? (the emphasis here is an effort to reformulate the same policy material, after all the activities have been completed, not when the policy is implemented).

And also the top-downers in carrying out their duties are more preoccupied with the problems of Grindle and Thomas [10]:

1) The effectiveness of government programs specifically formulated.

2) Their ability (elected official) directs the activities of the elements involved in implementing the program,

3) Control the activities of street level bureaucrats or man on the street from the possibility of disrupting the policies that have been formulated.

Sabatier suggested that Top Down's weaknesses were: (1) A policy that was formulated in a sustainable manner even though it was clearly formulated, made it difficult for the government to uncover the nuances of new problems developing in society, (2). It tends to give birth to a process of public policy that is not democratic, it is even possible to give birth to an authoritarian political regime. Both of these weaknesses have an impact on the implementation of policyn[10].

According to O. Jones[10], the implementation of policies / programs is determined by: (a) Perceptions of policy actors both at the central and regional levels towards the implementation of the policy in question; (b) Organization: organization, which is provided for policy implementation covering organizational structure, tasks and functions and impacts suggests the importance of institutions[11]. Traditionally, institutional approache in political science is related between the structure of government institutions and the content of policies. Institutional study m; (c) Delivery system (shipping policy or program) to the target group.

\section{b. Centralzied Authority}

Based on these two concepts, the mechanism of legality or the legal basis governing the authority of MSMEs with the main task of the function is more formal and its institutions include 
structures, the main task of the function is symbolic. Therefore, the local government does not have enough authority for its implementation even though the Surabaya City's regional policy already exists.

It is very ironic that there is an attraction between central and regional authorities. Actors' perceptions at the Regional Level through Policy can be observed or measured for success, if they have fulfilled some activities that are derivatives or delivery of central policies, activities taken by the center such as: the process of organizing forestry activities and procurement of goods for the target group (MSMEs)

The activities of local governments are: conducting marketing through exhibitions and competition for MSMEs. Interesting findings related to collaborative management

\section{(2) Jurisdiction-Based Management Collaborasi Model}

Therefore, the central authority is far from taking over regional authority in managing MSMEs, through the local government of Surabaya City to collaborate with SOEs in the procurement of resources, especially funds.

Initiation and similarity of perceptions between city-led actors (local managers) in order to conduct negotiations in the program are vertical and horizontal, in order to empower MSMEs, resulting in mutually beneficial solutions. Vertically active collaboration activities and collaboration strategies are opportunistic (horizontal dimensions). The dimension of vertical activity is the interaction of the behaviour of the actors following the pattern from the outside [12].

Jurisdiction Collaboration can be seen from the collaboration between the city government and BUMN or BUMD, such as: PT. Telkom in issuing Corporate Social Responsibility (CSR) as stated in Law No. 40 of 2007 concerning Limited Liability Companies, seems very successful in supporting the management of MSMEs in the City of Surabaya; through the application of an administrative Spirit of Public[13]. With good governance, the actors or leaders have been aware of the spirit and for some activities have succeeded in changing governance, table 2.

Table 2. Transition of Good Government Bureaucracy

\begin{tabular}{|l|l|}
\hline \multicolumn{1}{|c|}{ Governance } & Bureaucracy \\
\hline (1) Steering & (1) Rowing \\
(2) Empowering & (2) Service \\
(3) Competition & (3) Monopoly \\
(4) Mission-driven & (4) Role-driven \\
(5) Funding outcomes & (5) Budgeting Input \\
(6) Customer-driven & (6) Bureaucracy-driven \\
(7) Earning & (7) Spending \\
(8) Preventing & (8) Curing \\
(9) Team work / participator & (9) Hierarchy \\
(10) Market & (10) Organization \\
\hline
\end{tabular}

The spirit of competence is an effective issue for managing the UMKM in Surabaya, through Competency Activities such as: Economic Heroes. All three activities are expected to represent collaborations carried out by the government with SOEs and MSMEs. The city government develops a policy (Horizontal Dimension), when the city government must continue to carry out MSMEs activities, the city government implements policies and arrangements that 
do not have enough power to conduct MSMEs development activities, as well as MSMEs that do not have accessibility, then formulated strategic policies and own operations.

Although the results of the activities and results achieved cannot be achieved as expected in the Law or MSMEs policy.

\section{(3) Leading Sector Management Public Collaboration}

Of course it is interesting that it is leading with a sector in the management of MSMEs, including 3 (three) services, namely:

(1) Department of Cooperatives and MSMEs duty

(2) Commerce Department duty

(3) Department of Fisheries duty

Supposedly, in the implementation of Mayor Regulation 91 of 2008 concerning the Details of Tasks and Functions of the Surabaya City Service, the three departments were explicitly divided, so that the activities and achievements of the program objectives, each agency could be achieved effectively and efficiently.

Therefore the leading sector of MSMEs management has not been explicit. Then coordination is difficult. Each agency runs alone and the target group (MSMEs) tends to overlap. Thus, it can be seen that the weak achievement of MSMEs goals, namely the independence of MSMEs is also difficult to achieve.

Collaboration between government, BUMN, BUMD, and private entrepreneurs (Indomaret, Alfamart, and Superindo) through its CSR or through inter-private collaboration and MSMEs is non-formal, without the support of legality procedures.

Collaboration between the private sector and MSMEs of BUMN or BUMD does not have an impact on the independence of MSMEs.

In conclusion, collaboration which is one of the strategy choices to encourage the independence of MSMEs, conceptually and applicatively is still hampered by factors that are not expected from MSMEs, namely:

1. Strong legal formality or financial centralization

2. There is no leading sector driving collaboration

3. Low accountability of institutions

Meanwhile, the factors expected to appear secondary:

1. Partnership between local government and BUMN and BUMD (such as: PT. TELKOM, PT Pertamina, etc.), private sector with MSMEs through their CSR

2. The emergence of Higher Education institutions collaborating with MSMEs, in applying one of the Tri Dharma of Higher Education, namely community service, through the MOU with the Surabaya City Government, such as Desa Binaan

3. The emergence of collaboration between the private sector (minimarket) and MSMEs as one of the preconditions for the establishment of the minimarket. Although the collaboration carried out by the minimarket provides space for MSMEs to market their products (such as kebabs, juice, food and other beverages).

MSMEs provides benefits to the minimarket for $\mathrm{Rp}$. 600,000 per month, as part of a collective agreement without any formal legal (MOU).

Based on the three factors that are not expected to appear or are expected to occur in a secondary manner, it is necessary to reform the policies or programs of MSMEs, such as the explicit and clear division of authority for the development of MSMEs at the regional level, namely the effective decentralization of authority in the context of regional autonomy, both: 
procurement of personnel, and facilities, so that the regions are able to formulate strategic policies on the management of MSMEs such as:

(a) Data collection on the number of MSMEs (Data Based);

(b) Classification of MSMEs becomes: guided groups or initiations, middle or middle class groups and independent groups

(c) Providing an assessment as well as designing collaboration between the government and MSMEs that have entered the independent category.

(d) The three things above have consequences for the implementer:

1. Education and training (Fighting, motivation, creativity, etc.)

2. Production models: processes and results;

3. Marketing model

4. Institutional management: licensing (SIUP, TDP, PIRT Certificate, Halal), taxation, access to funding, involvement as a member of the sustainability cooperative institution

5. Registered by national and international standardization as a road map for going public

\section{Conclusion}

Based on the description of the previous chapters, it can be concluded as follows that the collaboration model that is implemented tends to lead to Jurisprodiction Based Management. The model has experienced significant obstacles: (1) Symbolistic and legal-formalistic, (2) Collaborative management has not been effective between local government, the private sector, and the community, (3) There is no policy that regulates MSMEs at the regional level as an interpretation of central policy, (4) The absence of a leading sector responsible for coordination of collaboration.

\section{References}

[1] M. Morris and associates, "Multi-Sectoral Collaboration and Economic Development: Lessons from England's Regional Development Agencies," Canada, 2010.

[2] R. Parker, "Governance and The Entrepreneurial Economy: A Comparative Analysis of Three Regions," Entrep. Theory Pract., pp. 1042-2587, 2008.

[3] X. Y. Mei, "Innovation and Collaboration: The Role of The National Government in Norway," Tour. Anal., vol. 18, no. 1083-5423/13, pp. 519-531, 2013.

[4] D. Swindell and H. Cheryl, "Collaborative Service Delivery: What Every Local Government Manager Should Know," Phoenix, 2013.

[5] S. Godenhjelm and J.-E. Johanson, "The Effect of Stakeholder Inclusion on Public Sector Project Innovation,” Finl. Int. Riview Adm. Sci., vol. 16, no. 00014, pp. 1-21, 2016.

[6] M. Kassen, "Promoting Public Cooperation In Government: Key Drivers, Regulation, and Barriers of The E-Collaboration Movement In Kazakhstan," Int. Rev. Adm. Sci. Eurasian Humanit. Institute, Kazakhstan, vol. 0, no. 0, pp. 1-20, 2018.

[7] L. Bouchard and and friends, "The Fundamentals of Cross-Sector Collaboration For Social Change to Promote Population Health," Glob. Health Promot., no. 1757-9759, pp. 1-10, 2017.

[8] A. Callofi and F. Gambarotto, "Cognitive Distance in Public Procurement and Public-Private Partnerships: An Analysis of the Construction Sector," Environ. Plan. C Gov. Policy, vol. 0, no. 0, pp. 1-19, 2016.

[9] M. B. Miles and A. M. Huberman, Qualitative Data Analysis (Terjemahan). Jakarta: UI Press, 2005.

[10] E. Lilik, Perencanaan, Implementasi dan Evaluasi Kebijakan atau Program (Suatu Kajian 
Teoritis dan Praktis). Surabaya: CV. Litera Meda Center, 2014.

[11] T. R. Dey, Understanding Public Policy Third Edition, Third. Prentice Hall International Inc.Englewood Cliff, N, 1978.

[12] R. Agranoff and M. McGuire, Collaborative Public Management: New Strategies for Local Government. Washington, D.C: Georgetown University Press, 2003.

[13] H. G. Frederickson, The Spirit of Public Administration. San Francisco: Jossey-Bass, 1997. 